\title{
Diversity of Lysophosphatidic Acid Receptor-Mediated Intracellular Calcium Signaling in Early Cortical Neurogenesis
}

\author{
Adrienne E. Dubin, Deron R. Herr, and Jerold Chun \\ Department of Molecular Biology, Dorris Neuroscience Center, The Scripps Research Institute, La Jolla, California 92037
}

Lysophosphatidic acid (LPA) is a membrane-derived lysophospholipid that can induce pleomorphic effects in neural progenitor cells (NPCs) from the cerebral cortex, including alterations in ionic conductance. LPA-induced, calcium-mediated conductance changes have been reported; however, the underlying molecular mechanisms have not been determined. We show here that activation of specific cognate receptors accounts for nearly all intracellular calcium responses evoked by LPA in acutely cultured nestin-positive NPCs from the developing mouse cerebral cortex. Fast-onset changes in intracellular calcium levels required release from thapsigargin-sensitive stores by a pertussis toxin-insensitive mechanism. The influx of extracellular calcium through $\mathrm{Cd}^{2+} / \mathrm{Ni}^{2+}$-insensitive influx pathways, approximately one-half of which were $\mathrm{Gd}^{3+}$ sensitive, contributed to the temporal diversity of responses. Quantitative reverse transcriptionPCR revealed the presence of all five known LPA receptors in primary NPCs, with prominent expression of $L_{P A}, L_{1} A_{2}$, and $L_{P A}$. Combined genetic and pharmacological studies indicated that NPC responses were mediated by $\mathrm{LPA}_{1}\left(\sim 30 \%\right.$ of the cells), $\mathrm{LPA}_{2}(\sim 30 \%)$, a combination of receptors on single cells $(\sim 30 \%)$, and non- $\mathrm{LPA}_{1,2,3}$ pathways $(\sim 10 \%)$. LPA responsivity was significantly reduced in more differentiated $\mathrm{TuJ} 1^{+}$cells within cultures. Calcium transients in a large proportion of LPA-responsive NPCs were also initiated by the closely related signaling lipid S1P (sphingosine-1-phosphate). These data demonstrate for the first time the involvement of LPA receptors in mediating surprisingly diverse NPC calcium responses involving multiple receptor subtypes that function within a single cell. Compared with other known factors, lysophospholipids represent the major activator of calcium signaling identified within NPCs at this early stage in corticogenesis.

\section{Introduction}

The importance of the bioactive lipid lysophosphatidic acid (LPA) in the nervous system is underscored by its biologically relevant concentrations in the developing brain (Das and Hajra, 1989), and the localization of its five known cognate G-proteincoupled receptors, $\mathrm{LPA}_{1-5}$, in developing and mature brain (Hecht et al., 1996; Contos and Chun, 2001; Contos et al., 2002; McGiffert et al., 2002; Noguchi et al., 2003; Choi et al., 2010). Genetic deletion of the first identified receptor $\left(\mathrm{LPA}_{1}\right)$ has revealed CNS phenotypes (Contos et al., 2000; Harrison et al., 2003; Estivill-Torrús et al., 2008). Furthermore, these mice reveal behavioral phenotypes reminiscent of schizophrenia, a neurological disorder with developmental etiology (Harrison et al., 2003). Recent in vitro and ex vivo studies have addressed the relationship of LPA receptor-mediated effects to cell fate during early corticogenesis (Kingsbury et al., 2003; Fukushima et al., 2007). Acute administration of LPA induces process retraction and inhibits migration in young cortical neurons (Fukushima et al., 2002),

\footnotetext{
Received Dec. 11, 2009; revised March 27, 2010; accepted April 9, 2010.

This work was supported by National Institutes of Health Grants MH051699 and DA019674 (J.C.). We gratefully acknowledge Danielle Letourneau and Hope Mirendil for critical review of this manuscript, and Dr. Kathy Spencer, Dr. Bialong Xiao, and Takashi Miyamoto for help with calcium imaging experiments.

Correspondence should be addressed to Jerold Chun, Department of Molecular Biology, The Scripps Research Institute, 10550 North Torrey Pines Road, ICND-118, La Jolla, CA 92037. E-mail: jchun@scripps.edu.

DOI:10.1523/JNEUROSCI.6151-09.2010

Copyright $\odot 2010$ the authors $\quad 0270-6474 / 10 / 307300-10 \$ 15.00 / 0$
}

and stimulates clustering and nuclear migration in nestinpositive neural progenitor cells (NPCs) (Fukushima et al., 2000). Ex vivo gain-of-function studies revealed that exogenous LPA induces thickening and abnormal folding of the cortex through $\mathrm{LPA}_{1}$ - and $\mathrm{LPA}_{2}$-dependent increases in neurons and decreases in programmed cell death (PCD) (Kingsbury et al., 2003). LPA activation promotes neuronal differentiation in long-term neurosphere cultures derived from murine E12 telencephalon in the presence of basic fibroblast growth factor (bFGF) (Fukushima et al., 2007). In many cases, the targets of exogenous LPA are unknown but may include NPCs, young neurons, and differentiating glia.

$\mathrm{Ca}_{\mathrm{i}}^{2+}$ signaling has been demonstrated to regulate progenitor and differentiated cell production (LoTurco et al., 1995; Haydar et al., 2000; Weissman et al., 2004), and dysregulated $\mathrm{Ca}_{\mathrm{i}}^{2+}$ signaling may underlie certain neurological diseases with developmental etiologies (Caviness et al., 1995). Tightly controlled regulation of NPC proliferation, PCD, and differentiation is critical for proper cortical development (Corbin et al., 2008). Fluctuations in $\mathrm{Ca}_{\mathrm{i}}^{2+}$ play diverse roles in nervous system development including differentiation of neural cells ( $\mathrm{Gu}$ and Spitzer, 1995; Spitzer et al., 2004), chemotaxis (Kumada and Komuro, 2004; Komuro and Kumada, 2005), proliferation (Lory et al., 2006), and morphology (Aizawa et al., 2004). These important neurodevelopmental processes are initiated by cells using intra- 
cellular and/or extracellular $\mathrm{Ca}^{2+}$ in distinct patterns (Berridge et al., 2000; Meyer zu Heringdorf, 2004).

As a group, LPA receptors activate G-proteins to modulate differentiation, migration, morphology, proliferation, survival, and cellular physiologies of many cell types (Gardell et al., 2006; Choi et al., 2010). All known LPA receptors are capable of modulating $\mathrm{Ca}_{\mathrm{i}}^{2+}$ (An et al., 1998; Bandoh et al., 1999; Lee et al., 2006, 2007; Yanagida et al., 2007). Since receptor-mediated intracellular $\mathrm{Ca}_{\mathrm{i}}^{2+}$ fluctuations play diverse roles in nervous system development (LoTurco et al., 1995; Haydar et al., 2000; Okada et al., 2003; Weissman et al., 2004), we tested whether exogenously applied LPA could evoke intracellular $\mathrm{Ca}_{\mathrm{i}}^{2+}$ responses in NPCs and used pharmacological and genetic approaches to identify the responsible LPA receptor subtypes, contrasting with possible non-G-protein-coupled receptor mechanisms. We further addressed downstream mechanisms involved in LPA-induced calcium signaling.

\section{Materials and Methods}

Animal husbandry. All animal protocols were approved by The Scripps Research Institute Animal Subjects Committee and are in accordance with National Institutes of Health guidelines and public law. Wild-type C57BL/6J, BALB/cByJ, and mixed background C57/129 mice were used during the course of these studies. Lpar1 ${ }^{-1-}$ (Contos et al., 2000), Lpar2 $^{-/-}$(Contos et al., 2002), and Lpar3 ${ }^{-1-}$ (Ye et al., 2005) mice were generated as previously described. Lpar1 ${ }^{-1-}$ and $L p a r 2^{-1-}$ embryos were obtained by crossing heterozygous females to heterozygous or homozygous knock-out males in a BALB/cByJ background $(N>10)$. Lpar $1^{-/-} /$Lpar $^{-1-} /$ Lpar $^{-1-}$ triple-null embryos were obtained by crossing Lpar1 $^{-1-} /$ Lpar2 $^{-/-} /$Lpar3 $^{+/-}$females to Lpar1 ${ }^{-/-} /$Lpar2 $^{-1-}$ / Lpar3 $^{-1-}$ males in a 129/SvJ, C57BL/6N mixed background (Ye, 2008). In all experiments, heterozygous and wild-type littermates were used as controls for homozygous embryos.

Cell culture. Timed-pregnant mice [day of plug, embryonic day 0.5 (E0.5)] were killed by cervical dislocation, and E12.5 dorsal telencephalic regions from individual embryos were dissected in ice-cold serum-free Opti-MEM-I (Invitrogen) supplemented with $20 \mathrm{~mm}$ D-glucose, and 1\% penicillin-streptomycin, in the absence of bFGF or EGF (epidermal growth factor), as described previously (Dubin et al., 1999). In studies using knock-out animals, the tail of each embryo was removed for genotyping. The dissected cortical regions of the telencephalon (which excludes ganglionic eminence, developing olfactory bulbs, and meninges) from individual embryos were placed in $1000 \mu \mathrm{l}$ (or larger dependent on the volume of the tissue) of Opti-MEM-I in plastic centrifuge tubes, gently triturated by glass pipette into small clusters $(<50$ cells), centrifuged at $150 \times g$, resuspended in $200 \mu \mathrm{l}$ of Opti-MEM-I, and aliquotted to the center of three or four 12-mm-diameter coverslips previously coated with Cell-Tak (Collaborative Research) in 24-well cluster plates. After settling $15 \mathrm{~min}$ in at $37^{\circ} \mathrm{C}$ in a $5 \% \mathrm{CO}_{2}$ incubator, $1 \mathrm{ml}$ of OptiMEM-I was gently added to each well and coverslips were removed for fura-2 AM loading beginning as early as 45 min later.

$\mathrm{Ca}^{2+}$ imaging. Alterations in $\mathrm{Ca}_{\mathrm{i}}^{2+}$ were determined using the ratiometric calcium indicator dye fura-2. Cells were loaded with fura-2 AM ( 8 $\mu \mathrm{M})$ in the presence of $1.5 \mu \mathrm{M}$ pluronic acid F-127, and incubated for $30-45 \mathrm{~min}$ at room temperature in the dark in $5 \mathrm{mM} \mathrm{Ca}^{2+}$ buffer containing the following (in $\mathrm{mM}$ ): $126 \mathrm{NaCl}, 5 \mathrm{KCl}, 1 \mathrm{MgCl}_{2}, 5 \mathrm{CaCl}_{2}, 10$ HEPES, buffered to $\mathrm{pH}$ 7.4. Loading was done on one coverslip at a time to avoid cytotoxicity during prolonged incubations in fura-2 AM and pluronic acid (data not shown). Just before testing, coverslips were briefly dipped in $5 \mathrm{~mm} \mathrm{Ca}^{2+}$ buffer, the edge blotted on a Kimwipe tissue and then secured to the bottom of a laminar flow perfusion chamber RC-25 (Warner Instruments) with vacuum grease. Buffer $\left(5 \mathrm{mM} \mathrm{Ca}^{2+}\right)$ was gently added and the chamber mounted on an Axiovert 200M microscope. Cells chosen for imaging included those in semiflat clusters where individual cells are clearly distinguishable, as well as around the perimeter of clusters in the plane of focus such that the imaged area was within a single cell avoiding overlying or underlying cells that might contribute to the signal. Cells were constantly perfused at room temperature $\left(\sim 23-25^{\circ} \mathrm{C}\right)$ at a rate of $3.3 \mathrm{ml} / \mathrm{min}$ (one chamber volume per 5-6 s) (Lee et al., 2007). For experiments aimed at determining the component of the response mediated by $\mathrm{Ca}^{2+}$ influx, cells were acutely exposed to a $\mathrm{Ca}^{2+}$-depleted solution (in mM: $140 \mathrm{NaCl}, 5 \mathrm{KCl}, 1 \mathrm{MgCl}_{2}, 1 \mathrm{EGTA}$, 10 HEPES, pH 7.4) or pretreated for 20-50 $\min$ in $1 \mu \mathrm{M}$ thapsigargin and tested for LPA responsiveness in the presence or absence (to ensure stores were depleted) of extracellular calcium. All compounds were applied by gravity feed bath perfusion (AutoMate Scientific). Fresh LPA-containing solutions were made from $1000 \times$ stocks just before (within $100 \mathrm{~s}$ ) use (i.e., addition to perfusion apparatus reservoir). Fura-2 imaging was performed as previously described (Lee et al., 2006, 2007). Briefly, images of fura-2-loaded cells with the excitation wavelength alternating between 340 and $380 \mathrm{~nm}$ were captured with a cooled CCD camera every $\sim 4 \mathrm{~s}$ After subtraction of background fluorescence, the ratio of fluorescence intensity emitted after excitation at 340 and $380 \mathrm{~nm}\left(F_{340} / F_{380}\right)$ was calculated (MetaFluor; Molecular Devices). The computer screen of the field of imaged cells (50-255 cells per field) (supplemental Fig. $1 \mathrm{~A}$, available at www.jneurosci.org as supplemental material) was saved for later comparison with immunohistochemical labeling (supplemental Fig. $1 B$, available at www.jneurosci.org as supplemental material). For pharmacological experiments with the specific $\mathrm{LPA}_{1} / \mathrm{LPA}_{3}$ inhibitor 3-(4-[4([1-(2-chlorophenyl)ethoxy]carbonyl amino)-3-methyl-5-isoxazolyl] benzylsulfonyl)propanoic acid (Ki16425) (Ohta et al., 2003), cells were exposed for 3-12 min to $10 \mu \mathrm{M}$ Ki16425 followed by $100 \mathrm{~s}$ in $300 \mathrm{nM} \mathrm{LPA}$ together with $10 \mu \mathrm{M}$ Ki16425 followed by $\sim 30 \mathrm{~s}$ in Ki16425 without agonist before washout. LPA was applied at $5 \mathrm{~min}$ intervals. A second $\mathrm{LPA}_{1} / \mathrm{LPA}_{3}$ inhibitor ( $S$ )-phosphoric acid mono-(2-octadec-9enoylamino-3-[4-(pyridine-2-ylmethoxy)-phenyl]-propyl)ester [VPC $32183(S)$ ] was tested similarly. Criteria for classification as a "responder" included the initiation of the response (increase or decrease in intracellular calcium) after a stable baseline within $100 \mathrm{~s}$ after agonist solution reached the recording chamber. Experiments to test the role of pertussis toxin (PTX)-sensitive G-proteins (e.g., $G_{\alpha i} / G_{\alpha o}$ ) were done after $4-8 \mathrm{~h}$ incubation in the presence of $100 \mathrm{ng} / \mathrm{ml} \mathrm{PTX}$ at $37^{\circ} \mathrm{C}$. $\mathrm{GdCl}_{3}(10-100$ $\mu \mathrm{M})$ incubation was done on-line after exposure to LPA.

Immunohistochemistry. The identification of imaged cells as NPCs or differentiating neurons was made by immunohistochemical labeling for nestin and $\beta$-tubulin III (TuJ1), respectively. At the end of each imaging experiment, the coverslip was carefully removed from the chamber and submerged in $4 \%$ paraformaldehyde and kept at $4^{\circ} \mathrm{C}$ before staining. Coverslips were washed with PBS and incubated with blocking solution (2.5\% BSA, $0.3 \%$ Triton X-100 in PBS) for $1 \mathrm{~h}$ before antibody labeling. Primary antibodies were diluted 1:500 in blocking solution and applied to coverslips overnight at $4^{\circ} \mathrm{C}$ with agitation. After rinsing, coverslips were incubated in secondary antibodies (e.g., Alexa Fluor 488-conjugated anti-mouse IgG (Invitrogen) and Cy3-conjugated anti-rabbit IgG (Millipore) at 1:500 for $2 \mathrm{~h}$. After PBS rinses, all coverslips were counterstained with 4',6-diamidino-2-phenylindole (DAPI) and mounted on glass microscope slides in Vectashield (Vector Laboratories). Coverslips were examined and photographed using a Zeiss Axioskop fluorescence microscope with rhodamine, fluorescein, or DAPI filters.

Quantitative reverse transcription-PCR. Total RNA was isolated from embryos at E12.5 using RNeasy Protect Mini kit (QIAGEN). Approximately $5 \mu \mathrm{g}$ of each sample was DNase-treated and primed with oligo-dT before cDNA synthesis with SuperScript II reverse transcriptase (Invitrogen). Targets were amplified with iQ SYBR Green supermix (Bio-Rad) on a Bio-Rad iCycler using gene-specific primer pairs that flank an intron. To obtain absolute quantification of the target genes to compare between receptor subtypes and across ages, standard curves were established using plasmid samples containing reference sequences at known concentrations.

Data analysis. A change in intracellular calcium level was scored as a response if the change over baseline was at least $20 \%$ unless the previous baseline revealed significant fluctuations and the threshold change in ratio was increased to $50 \%$. After thapsigargin exposure, the latency of responses was often $>100 \mathrm{~s}$ and the cutoff time for a response was increased from 100 to $180 \mathrm{~s}$ since the onset of the slowly increasing responses was difficult to determine accurately. Occasionally adjacent 
A

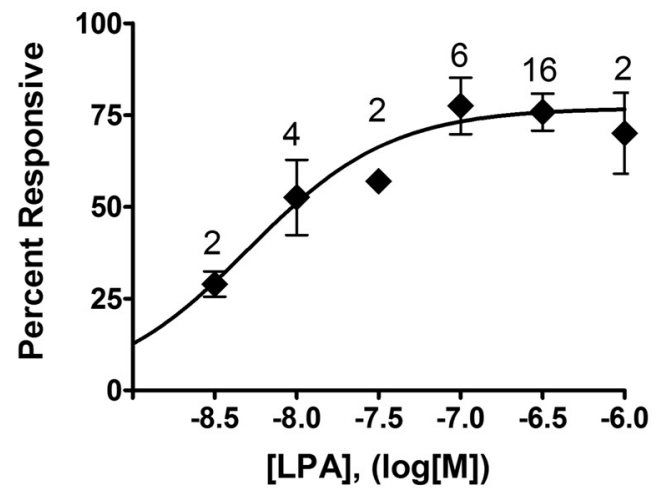

B

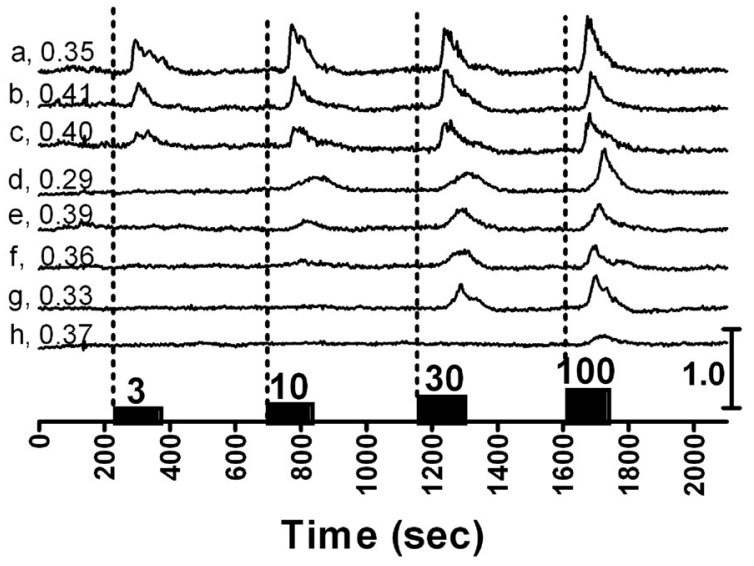

C

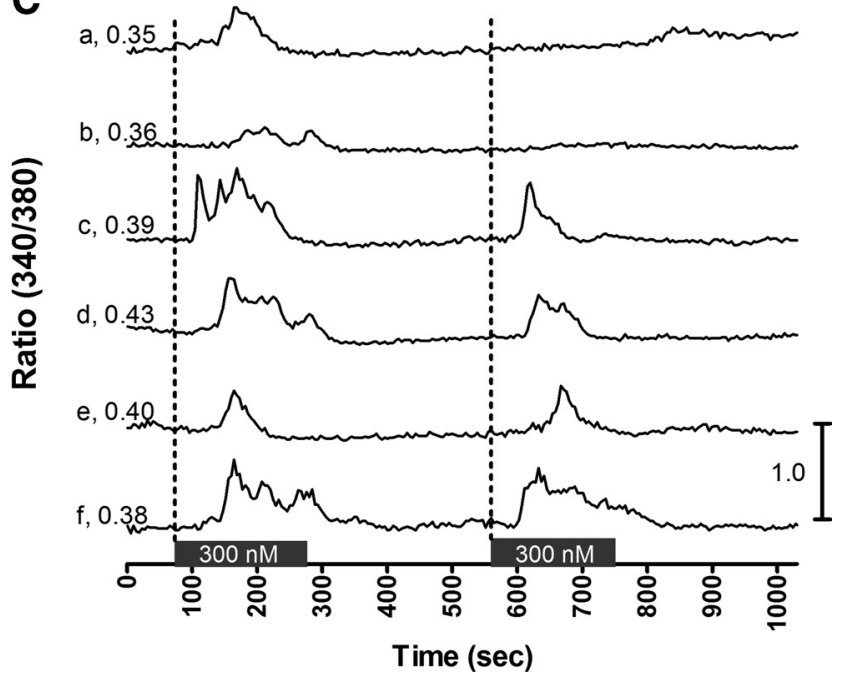

Figure 1. Submicromolar concentrations of $L P A$ increase $\mathrm{Ca}_{i}^{2+}$ in nestin ${ }^{+}$cells in cluster cultures from wild-type E12.5 murine dorsal telencephalon. $A$, LPA increases the percentage of responsive cells in a concentration-dependent manner. The percentage of cells responsive to the indicated concentration of LPA normalized to the subsequent response to either 300 or 1000 $\mathrm{nm}$ is plotted. Each point represents the mean \pm SEM for the number of separate experiments shown above each data point. The $\mathrm{EC}_{50}(5 \mathrm{~nm}$ with $95 \%$ confidence interval of 2-12 nм) was determined by fitting a sigmoidal curve to the data while constraining the bottom value to 0 . Similar results for the increase in percentage of responsive cells were observed in separate experiments in which a single low concentration was applied multiple times followed by exposure to $300 \mathrm{~nm}$. All classes of response are included $\left(5 \mathrm{~mm} \mathrm{Ca}{ }^{2+}\right) \cdot B$, The apparent $\mathrm{EC}_{50}$ for $\mathrm{LPA}$ sensitivity in individual cells reveals significant cell-to-cell variability. Examples of reversible increases in $\mathrm{Ca}_{\mathrm{i}}^{2+}$ in individual cells in response to LPA applied at the indicated concentrations $3,10,30$, and $100 \mathrm{~nm}$ (duration indicated by bars). The apparent thresholds for responses to LPA were $\leq 3 \mathrm{~nm}$ (traces $a-c), 10 \mathrm{~nm}$ (traces $d-f), 30 \mathrm{~nm}(\operatorname{trace} f, g), 100 \mathrm{~nm}$ (trace $h)$. The traces were nudged for clarity (GraphPad Prism 4.0). Calibration: $F_{340} / F_{380}=1.0$. Average baseline ratio, $\sim 0.4$ (indicated to the left of each trace). C, The extent of desensitization to repeated exposures to LPA (tachyphylaxis) reveals cellular heterogeneity. Wild-type cells were challenged twice fields with identical response profiles were observed and these were counted only once. Population data were compared using one-way ANOVA with Tukey's post hoc multiple-comparison test (GraphPad Prism 4) (see Figs. 2, 6, 7).

Reagents. The specific $\mathrm{LPA}_{1} / \mathrm{LPA}_{3}$ inhibitor Ki16425 was a gift from Kirin Brewery. LPA (1-oleoyl-2-hydroxy-sn-glycero-3-phosphate) and VPC 32183(S) were purchased from Avanti Polar Lipids. LPA was thoroughly dissolved in Milli-Q water and used fresh or stored frozen as a 5 mM stock solution in glass tubes. LPA was diluted to the indicated concentrations in extracellular saline and applied at concentrations ranging from $10 \mathrm{~nm}$ to $1 \mu \mathrm{M}$. Stock solutions of $1 \mathrm{~mm}$ sphingosine-1-phosphate (S1P) (Biomol) were made by dissolving in 100\% methanol, aliquotting to glass tubes, and storing at $-20^{\circ} \mathrm{C}$ before use. Thapsigargin (SigmaAldrich) was prepared from a 2 mM stock in DMSO. PTX (List Biological Laboratories) was dissolved in water at $100 \mu \mathrm{g} / \mathrm{ml}$. Glutamate, $\mathrm{CdCl}_{2}$, and $\mathrm{NiCl}_{2}$ were purchased from Sigma-Aldrich and dissolved in water as 5000,3000 , and $10,000 \times$ stock solutions. Pituitary adenylate cyclase activating polypeptide-38 (PACAP) (Sigma-Aldrich) was reconstituted as 1 $\mu \mathrm{M}$ in water and diluted to $3 \mathrm{~nm}$ in buffer before testing.

\section{Results}

Intracellular calcium levels in wild-type, nestin-immunoreactive NPCs are dynamically modulated by LPA

Submicromolar LPA concentrations modulated intracellular $\mathrm{Ca}^{2+}$ levels $\left(\mathrm{Ca}_{\mathrm{i}}^{2+}\right)$ in $\sim 75 \%$ of cells maintained in $\mathrm{Ca}^{2+}$ containing solution ( $5 \mathrm{mM} \mathrm{Ca}^{2+}$ buffer). Since spontaneous fluctuations of $\mathrm{Ca}_{\mathrm{i}}^{2+}$ were occasionally observed [consistent with previous reports (Owens and Kriegstein, 1998; Owens et al., 2000)], the criteria for an "LPA-dependent" response were based on the timing after LPA arrival to the recording chamber (latency, $\leq 100 \mathrm{~s}$ ) and reversibility of the calcium response (for additional criteria, see Materials and Methods). Responses to 100-300 nM LPA were reversible and could often be elicited multiple times (Fig. 1). Since clusters of NPCs can be electrically coupled in the developing cortex (LoTurco and Kriegstein, 1991), we addressed whether intercellular transmission of the $\mathrm{Ca}^{2+}$ signal overestimated the fraction of cells responding directly to LPA. Several lines of evidence indicated that nearly all cells are activated by LPA through cell-intrinsic mechanisms. First, responsive cells were observed to be randomly distributed throughout clusters adjacent to nonresponsive cells (supplemental Fig. 1C, available at www.jneurosci.org as supplemental material). Second, large LPA-induced $\mathrm{Ca}_{i}^{2+}$ responses were observed in single cells of multicellular clusters. Third, the onset of $\mathrm{Ca}_{\mathrm{i}}^{2+}$ responses observed in a cluster often revealed no significant timing differences (i.e., there was no evidence of waves). Fourth, other agonists evoked calcium responses in only a small proportion of cells in a cluster (e.g., ATP and PACAP), and these cells were nonadjacent. Finally, pharmacological studies (see below) indicated that activation of different cells in a cluster appeared to be receptor subtype dependent. Occasionally two adjacent fields revealed nearly identical response profiles, but this was rare and could be attributable to fields overlapping a single cell. These results are consistent with the findings that ventricular zone (VZ) cells in mouse E12-E13 telencephalon slices had mean input resistances and cell capacitances consistent with a single-cell electrical compartment (i.e., not coupled) (Albrieux et al., 2004).

Most nestin-immunoreactive cells responded to low nanomolar concentrations of LPA (Fig. 1). LPA as low as 3 nM pro-

with $300 \mathrm{~nm}$ LPA during the times indicated by the bars. Traces $a, b$, Nearly complete tachyphylaxis; traces $c, d$, moderate tachyphylaxis; tracese,$f$, little tachyphylaxis. The basal ratio is similar in all cases (shown at the beginning of each trace). Calibration: $F_{340} / F_{380}=1.0$. 


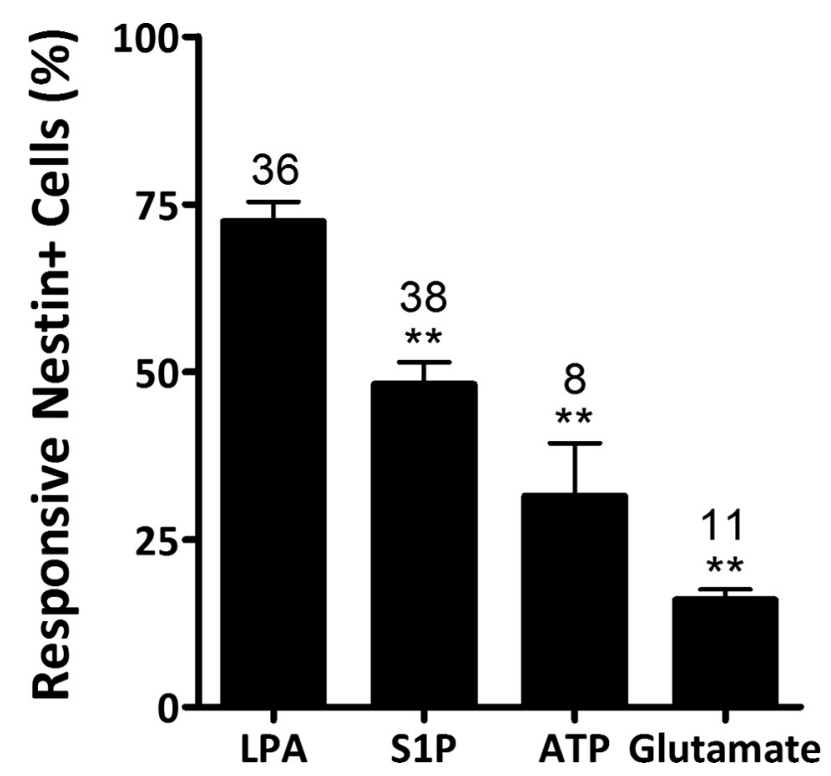

Figure 2. LPA activates a higher proportion of cells compared with other tested agonists in wild-type nestin ${ }^{+}$NPCs. Cells were challenged with LPA (100-1000 nM), S1P (1 $\left.\mu \mathrm{M}\right), \operatorname{ATP}(100$ $\mu \mathrm{m})$, or glutamate $(100-500 \mu \mathrm{m})$. Shown are means \pm SEM for the number of separate experiments indicated above each bar. ${ }^{* *} p<0.001$ compared with LPA (supplemental Table $1 A$, available at www.jneurosci.org as supplemental material).

duced responses in $\sim 25 \%$ of the cells (Fig. $1 A, B$, traces $a-c$ ). At $100 \mathrm{nM}, \sim 75 \%$ of the cells responded, similar to proportions observed with higher (300-1000 nM) concentrations of LPA. The percentage of responsive cells increased as the field of cells was exposed to higher concentrations (e.g., 10-100 nm LPA) [Fig. $1 B$, traces $d, e(10 \mathrm{nM}) ; f, g(30 \mathrm{nM}) ; h(100 \mathrm{nM})]$. Thus, the proportion of responding cells (Fig. $1 A$ ), as well as the magnitude of the response to LPA (data not shown), increased in a concentrationdependent manner. $F_{340} / F_{380}$ ratios achieved in these experiments were far from saturating since the average maximal ratio change elicited by $1 \mu \mathrm{M}$ ionomycin was $\sim 20$-fold the baseline (130 cells from two separate experiments), an increase not observed after LPA exposure (Fig. $1 B$; data not shown). In most cells, the extent of tachyphylaxis to a single concentration (300 $\mathrm{nM}$ ) of LPA was minimal (Fig. $1 C$, traces $e, f$ ), but there was extensive variability from cell to cell (Fig. $1 C$ ). After 5 min extensive washout, the response to a second, $300 \mathrm{nM} \mathrm{LPA}$ challenge ranged from near zero (Fig. $1 C$, traces $a, b$ ) to $\sim 120 \%$ (data not shown) of the initial response. LPA-induced responses showed no apparent sensitization in these experiments, a result that is essential for drawing conclusions from pharmacological experiments using Ki16425 (see below).

Approximately $75 \%$ of wild-type cells responded to LPA at $100-1000 \mathrm{~nm}(72.4 \pm 2.9 \% ; n=36)$ (Fig. 2). The high proportion of cells responding to LPA with increases in $\mathrm{Ca}_{\mathrm{i}}^{2+}$ is in contrast to the percentage of cells responding to S1P, ATP, and glutamate ( $\sim 20-50 \%)$ (Fig. 2; supplemental Table 1A, available at www.jneurosci.org as supplemental material). PACAPdependent signaling is an early event in corticogenesis (Suh et al., 2001) and receptors are capable of modulating intracellular calcium levels (Nicot and DiCicco-Bloom, 2001). Preliminary experiments indicated that PACAP elicited responses in $\sim 25 \%$ of cells, and these cells were a subset of those sensitive to LPA (data not shown).

Temporal heterogeneity of $\mathrm{Ca}_{\mathrm{i}}^{2+}$ responses was observed in individual cells bathed in $\mathrm{Ca}^{2+}$-containing solution (Fig. 3). In-

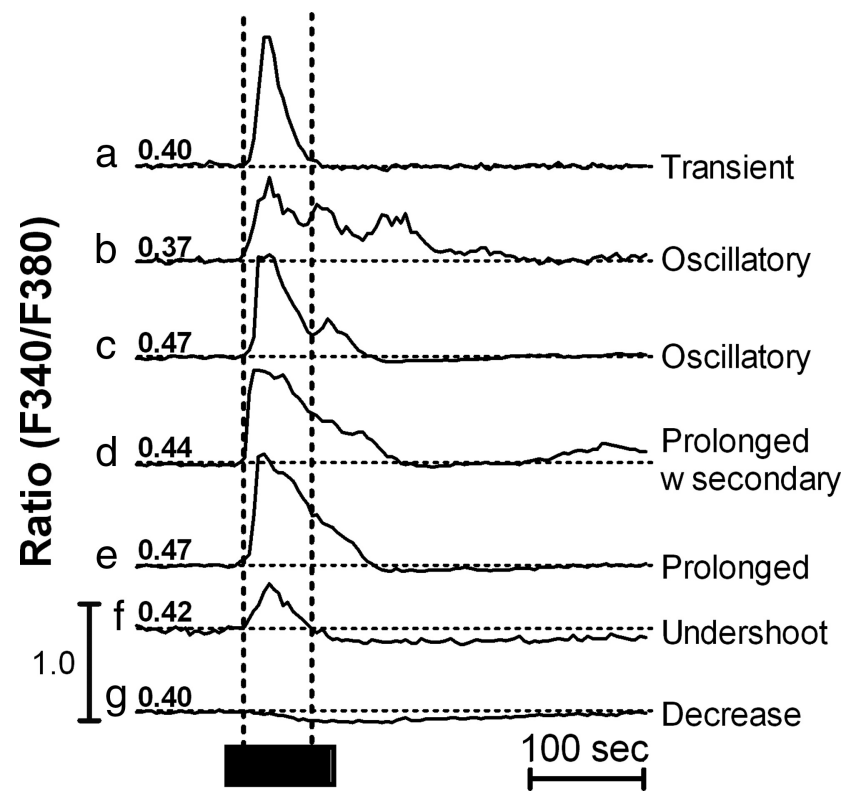

Figure 3. $L P A$-induced $\mathrm{Ca}_{\mathrm{i}}^{2+}$ responses are heterogeneous. $\mathrm{LPA}$-induced responses in the presence of extracellular calcium $\left(5 \mathrm{~mm} \mathrm{Ca}^{2+}\right)$ were observed after a $\sim 15 \mathrm{~s}$ delay. Although there is some variability in the time to peak, cells revealed striking variability in the time course of the response, particularly in the declining phase of the initial increase and subsequent apparent secondary effects (undershoot or increase after a significant delay). The transient response is similar to that observed in the absence of extracellular $\mathrm{Ca}^{2+}$ (see text). The basal ratio is shown at the beginning of each trace. Calibration: $F_{340} / F_{380}=1.0$.

tracellular calcium was increased in nearly every responsive cell (typical examples are shown in Fig. $3 a-f$ ); however, a small population of cells $(1-2 \%)$ revealed a reversible decrease in $\mathrm{Ca}^{2+}$ (Fig. $3 g$ ). In calcium-containing buffer, a minority of cells revealed an increase in $\mathrm{Ca}_{\mathrm{i}}^{2+}$ after a short lag, which decreased to basal levels within $\sim 100$ s of response onset (Fig. $3 a$ ), similar to the response to LPA in the absence of extracellular calcium (see below). Most cells responded to LPA with temporally complex fluctuations in $\mathrm{Ca}^{2+}$ (Fig. $3 b-f$ ). Transient increases could be followed by an "undershoot" of the basal $\mathrm{Ca}_{\mathrm{i}}^{2+}$ that slowly returned to baseline (Fig. $3 f$ ). Longer-lasting responses could support oscillations (Fig. $3 b, c$ ) or be followed by a secondary increase that was smaller than the initial response (Fig. $3 d$ ). The mechanism underlying the decrease in calcium levels is not known but may involve stimulation of transport molecules that decrease cytosolic calcium. The heterogeneity of responses may reflect the components of the calcium "tool kit" (Berridge et al., 2000) expressed by individual cells or receptor-specific $\mathrm{Ca}^{2+}$ signaling pathways (see Discussion).

LPA increases intracellular calcium via release of $\mathrm{Ca}^{2+}$ from intracellular stores and influx of extracellular $\mathrm{Ca}^{2+}$

The striking heterogeneity of observed LPA-induced responses suggested that the duration of responses might be dependent on both release from intracellular stores and influx of external $\mathrm{Ca}^{2+}$. We therefore next determined the dependence of the LPA response profile on release of $\mathrm{Ca}^{2+}$ from intracellular $\mathrm{Ca}^{2+}$ stores. In the absence of extracellular $\mathrm{Ca}^{2+}$, responses to LPA (300 nM) were observed in a similar proportion of cells as in the presence of $\mathrm{Ca}^{2+}(61 \pm 6 \%$ in three separate experiments; $50-200$ cells/ experiment) but were far less variable in time course, usually characterized by a fast transient rise in $\mathrm{Ca}_{\mathrm{i}}^{2+}$ after a 15-30 s delay. The time between half-maximal response rise and fall $\left(t_{50}\right)$ was $34 \pm 7 \mathrm{~s}$ (three separate experiments), and the time to decay to 
basal levels in the continued presence of LPA was 50-100 s. In the presence of extracellular $\mathrm{Ca}^{2+}$, the response time course was significantly more prolonged ( $t_{50}$ was $101 \pm 9 \mathrm{~s}$, 14 separate experiments; $p<0.0005$ time for response to decay in $5 \mathrm{mM} \mathrm{Ca}^{2+}$ buffer vs $0 \mathrm{mM} \mathrm{Ca}^{2+}$ buffer). The dependence of the initial fast transient rise in intracellular $\mathrm{Ca}^{2+}$ and influx of external calcium on intracellular store release was investigated by depleting stores using the $\mathrm{Ca}^{2+}$-ATPase inhibitor thapsigargin. Thapsigargin (1 $\mu \mathrm{M})$ completely abolished LPA-induced effects when cells were tested in the absence of calcium, confirming the depletion of stores (data not shown). In the presence of extracellular $\mathrm{Ca}^{2+}$, the fast transient response was abolished. However, under these conditions, reversible, slowly rising increases were observed (supplemental Fig. 2, available at www.jneurosci.org as supplemental material). Additional evidence that $\mathrm{Ca}^{2+}$ influx through plasma membrane ion channels contributed to the duration of the $\mathrm{Ca}_{\mathrm{i}}^{2+}$ response was the reversible inhibition of the prolonged response by short exposure of external $\mathrm{Gd}^{3+}(10-100 \mu \mathrm{M})$ in approximately one-half of the cells (supplemental Fig. 3, available at www.jneurosci.org as supplemental material). Since $\mathrm{Gd}^{3+}$ is known to block $\mathrm{Ca}_{\mathrm{v}}$ channels (Biagi and Enyeart, 1990), we tested whether LPA-induced responses could be inhibited by the $\mathrm{Ca}_{\mathrm{v}}$ channel blockers $\mathrm{Cd}^{2+}$ and $\mathrm{Ni}^{2+}$ (Hille, 2001). There was no obvious effect of $300 \mu \mathrm{M} \mathrm{Cd}^{2+}$ and $100 \mu \mathrm{M} \mathrm{Ni}^{2+}$ (applied before and during $300 \mathrm{~nm}$ LPA exposure) on LPA responsiveness, indicating that $\mathrm{Ca}^{2+}$ influx is not mediated by $\mathrm{Cd}^{2+}$ - or $\mathrm{Ni}^{2+}$ sensitive channels (supplemental Fig. 4, available at www. jneurosci.org as supplemental material).

Although LPA-induced $\mathrm{Ca}^{2+}$ transients are likely to be mediated by activation of $\mathrm{G}_{\alpha \mathrm{q}}$, calcium signaling can also be modulated by $G_{\alpha \mathrm{i}} / \mathrm{G}_{\alpha \mathrm{o}}$ activation in other systems (Lee et al., 2007). Therefore, we tested whether LPA-induced responses were sensitive to PTX. There were no differences observed in the proportion of LPA-sensitive cells or the character of the averaged response compared with control cells after a $4-6$ h preincubation with PTX (100 ng/ml) (supplemental Fig. 5A, available at www.jneurosci.org as supplemental material). PTX-mediated inhibition of $\mathrm{G}_{\alpha \mathrm{i}}$ in NPCs was confirmed by cAMP assay (supplemental Fig. 5B, available at www.jneurosci.org as supplemental material).

\section{LPA responsiveness is reduced in differentiated}

$\mathrm{TuJ1}^{+} /$nestin $^{-}$cortical neurons

The percentage of TuJ1 ${ }^{+}$cells that did not immunolabel for nestin (cells differentiating into neurons) in E12.5 cluster cultures ranged from 1 to $15 \%$, with an average of $9.8 \pm 2.1 \%(n=10$ separate cultures). The proportion of $\mathrm{TuJ}^{+}{ }^{+}$cells responsive to LPA $(25 \pm 5 \%)$ was significantly reduced compared with the proportion of all cells in these same cultures [78.6 $\pm 2.8 \%(n=$ $10) ; p<5 \mathrm{e}-8]$. The responsiveness of $\mathrm{TuJ} 1^{+}$cells to S1P was also reduced $(20 \pm 6 \% ; p<0.002)$ from that observed for all cells $(53 \pm 6 \%, n=9) . \mathrm{TuJ} 1^{+}$cells revealed a spectrum of heterogeneity similar to nestin ${ }^{+}$cells (transient, prolonged, prolonged with oscillatory component or subsequent increases or decreases after return of response to baseline). These data suggest that, at this stage in cortical development, calcium signaling is modulated by LPA (as well as S1P) in most neuroblasts but that most differentiating neurons lose this ability. They further suggest that an in vivo critical period for bioactive lipid signaling in cortical development may exist.

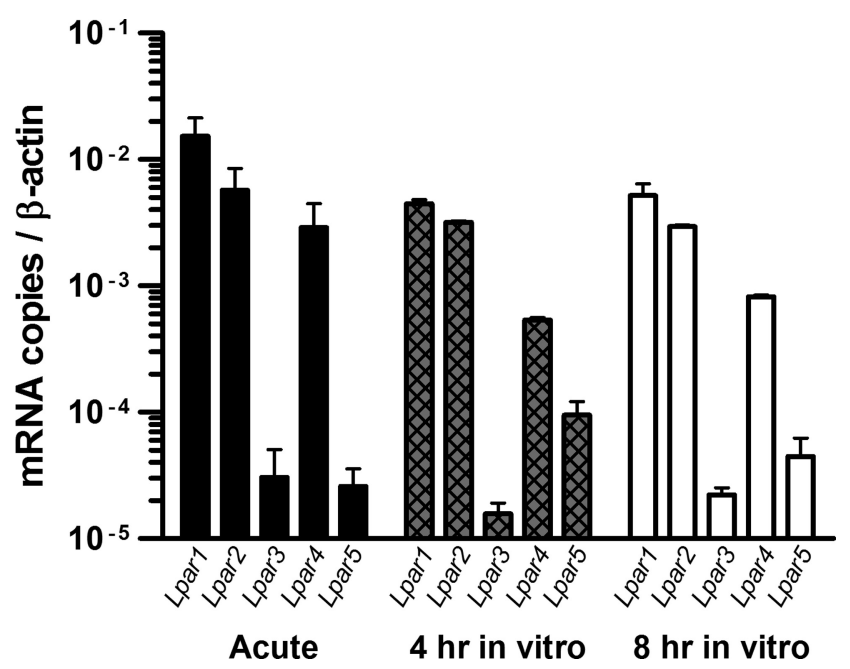

Figure 4. Significant levels of all LPA receptor transcripts from E12.5 isolated telencephalon. Quantitative RT-PCR was used to determine the mRNA copy number for LPA receptors $L P A_{1-5}$ from acutely isolated telencephalon (left), and from cells plated on Cell-Tak and assayed $4 \mathrm{~h}$ (middle) and $8 \mathrm{~h}$ (right) after culturing in serum-free medium. $\beta$-Actin was used to normalize receptor mRNA copy number. Error bars indicate SEM.

\section{LPA receptor mRNA expression in cultured E12.5 cortex}

Previous results have revealed prominent expression of $\mathrm{LPA}_{1}$ and $\mathrm{LPA}_{2}$ in early embryonic cortices (Contos et al., 2000; Contos and

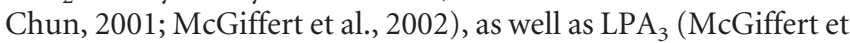
al., 2002; Ohuchi et al., 2008). Since that time, two novel Ki16425-insensitive LPA receptors have been identified that mobilize $\mathrm{Ca}^{2+}$ in recombinant expression systems (Noguchi et al., 2003; Lee et al., 2006, 2007) and may be expressed in the embryonic brain (Ohuchi et al., 2008). We therefore used quantitative reverse transcription (RT)-PCR to quantify the mRNA expression in E12.5 mouse telencephalon. As previously reported, $\mathrm{LPA}_{1}$ and $\mathrm{LPA}_{2}$ were the predominant receptors expressed; however, significant levels of $\mathrm{LPA}_{3}, \mathrm{LPA}_{4}$, and $\mathrm{LPA}_{5}$ were also observed. The relative abundance was $1 \sim 2 \sim 4 \ggg 3,5$ (Fig. 4 ). The profile observed from acutely isolated cells was similar to that observed up to $8 \mathrm{~h}$ in culture, indicating that, during the course of the calcium imaging studies, there was little change in the LPA receptor mRNA expressed by cells in culture.

\section{Pharmacological manipulation reveals that multiple LPA receptor subtypes are activated in NPCs to modulate intracellular $\mathrm{Ca}^{2+}$}

To determine whether LPA-induced calcium mobilization was mediated by a single receptor or multiple receptors, cortical NPCs were treated with the selective antagonist Ki16425. This compound effectively inhibits $\mathrm{LPA}_{1}$ and $\mathrm{LPA}_{3}$ and is inactive against the other known LPA receptors at low micromolar concentrations (Ohta et al., 2003; Lee et al., 2006, 2007). To avoid any potential complications of tachyphylaxis, cultures were first tested in the presence of antagonist. Cultures were incubated with the antagonist $(10 \mu \mathrm{M})$ for at least $5 \mathrm{~min}$ before application of 300 nM LPA in the continued presence of antagonist. The percentage of responsive wild-type NPCs was reduced to $47 \pm 4 \%(n=7)$ from $\sim 75 \%$ (observed in $0.1 \%$ DMSO vehicle controls) in the presence of this $\mathrm{LPA}_{1 / 3}$ antagonist. Importantly, extensive washout $(>10 \mathrm{~min})$ of Ki16425 resulted in a slowly developing responsiveness to LPA in these cells, consistent with the known reversible activity of Ki16425 (Ohta et al., 2003), which recovered to control proportions of sensitivity to LPA $(74 \pm 3 \%$; $n=4)$. In 


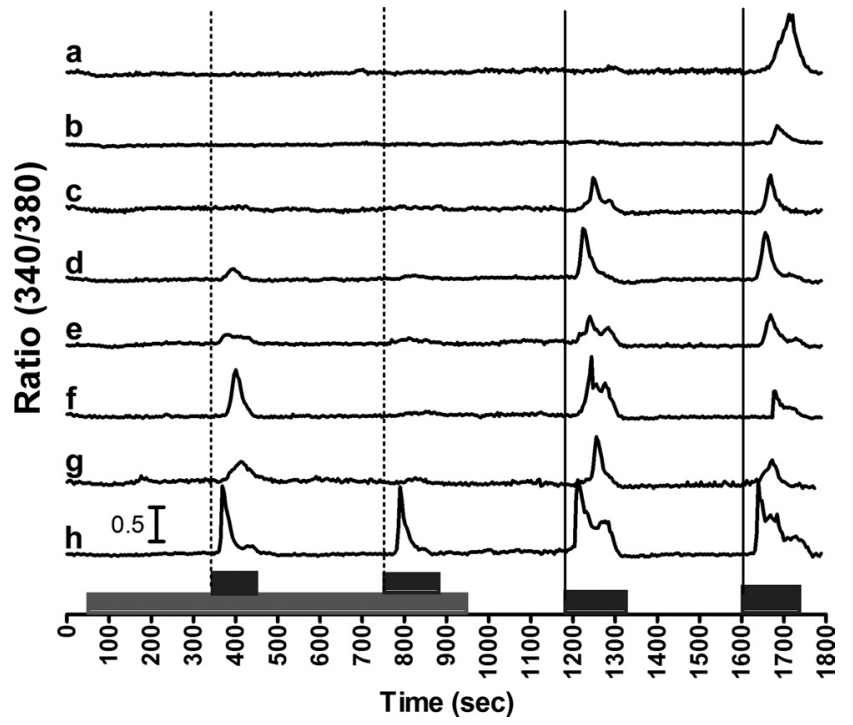

Figure 5. Examples of wild-type cells revealing Ki16425-sensitive and Ki16425-insensitive responses. Cells were continuously perfused with extracellular saline $\left(5 \mathrm{~mm} \mathrm{Ca}^{2+}\right)$ and at $50 \mathrm{~s}$ were exposed to $10 \mu \mathrm{m}$ Ki16425 for the duration indicated by the light gray bar. After $5 \mathrm{~min}$ exposure to antagonist, cells were challenged with $300 \mathrm{~nm} \mathrm{LPA} \mathrm{(dark} \mathrm{gray} \mathrm{bar)} \mathrm{in} \mathrm{the} \mathrm{continued}$ presence of Ki16425 for $100 \mathrm{~s}$, followed by Ki16425 alone for $5 \mathrm{~min}$ before a second challenge with $300 \mathrm{~nm}$ LPA/Ki16425. A minute after LPA washout, antagonist was removed and the cells were challenged twice with $300 \mathrm{~nm}$ LPA made at 5 min intervals. See text for discussion. Calibration: $F_{340} / F_{380}=0.5$

the experiment shown in Figure 5, we incubated wild-type cultures for $15 \mathrm{~min}$ in Ki16425 $(10 \mu \mathrm{M})$ and challenged cells with LPA (300 nM; dark gray bars) after 5-7 and 10-12 min in the presence of Ki16425 (10 $\mu \mathrm{M}$; light gray bar) followed by extensive rinsing and subsequent challenges with $300 \mathrm{nM} \mathrm{LPA}$. A variety of outcomes were observed. In the first class of outcomes (examples in Fig. $5 a-c$ ), responses were not observed in the presence of Ki16425 but were observed only during washout of Kil6425. Traces $a$ and $b$ reveal responses from individual cells that responded to LPA only after $10 \mathrm{~min}$ of washout. Trace $c$ shows similar responses at 5 and $10 \mathrm{~min}$ after washout. These data are consistent with the expression of $\mathrm{LPA}_{1 / 3}$, but not $\mathrm{LPA}_{2}$ or other Ki16425-insensitive receptors. In the second class (Fig. $5 d, e$ ), small nonsensitizing responses were observed during Ki16425 exposure and larger calcium signals were apparent after washout, consistent with the expression of Ki16425-insensitive receptors and $\mathrm{LPA}_{1 / 3}$. It is not likely that the responses observed after Ki16425 washout are attributable to sensitization since significantly enhanced responses were not observed after DMSO in control experiments (data not shown); however, we cannot rule out this possibility in some cases. In the third class (Fig. $5 f, g$ ), tachyphylaxis of the LPA response during the continued presence of Ki16425 is observed followed by large responses after antagonist washout consistent with the expression of both $\mathrm{LPA}_{2}$ [and/or Ki16425 insensitive receptor(s) revealing tachyphylaxis] and $\mathrm{LPA}_{1 / 3}$. Finally, in the fourth class (Fig. 5h), LPA responses revealed little tachyphylaxis both in the presence and absence of Ki16425; however, under the latter condition, large responses had reproducibly different profiles than those in Ki16425 (e.g., oscillatory calcium levels) consistent with the presence of both Ki16425-sensitive and -insensitive receptor populations. Class 1 is consistent with LPA-sensitive cell populations expressing $\mathrm{LPA}_{1 / 3}$ but not $\mathrm{LPA}_{2 / 4 / 5}$ (which would have been observed during antagonist exposure), and classes $2-4$ are consistent with cells

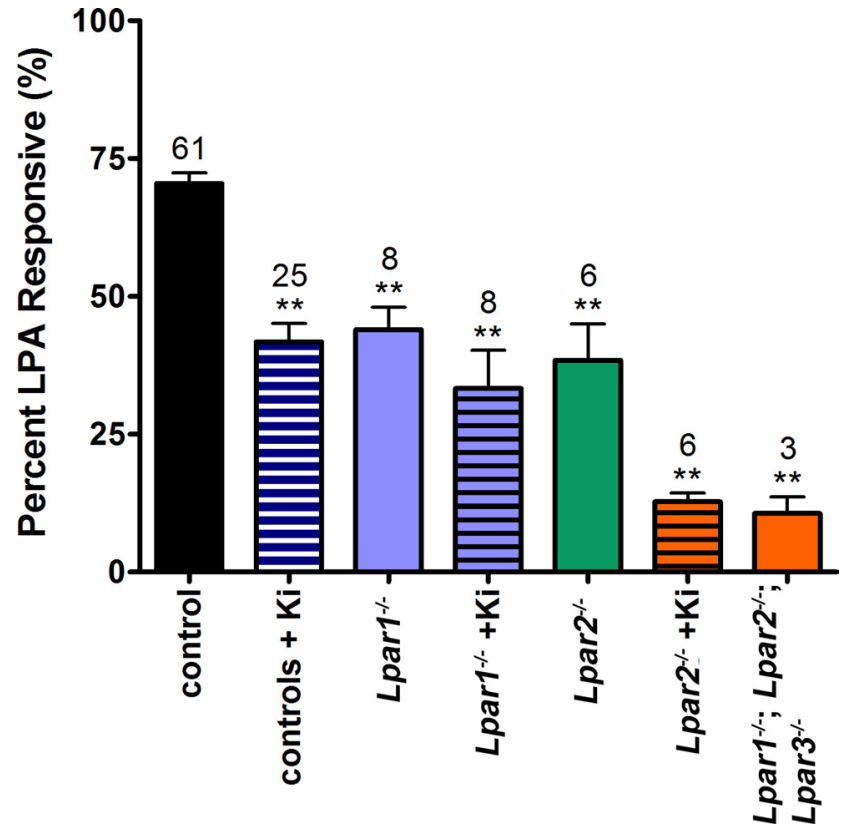

Figure 6. $\quad \mathrm{LPA}_{1}$ and $\mathrm{LPA}_{2}$ are the predominant receptor subtypes expressed in nestin ${ }^{+}$ NPCs that evoke changes in intracellular calcium levels. The percentage of LPA-responsive cells in cultures derived from the indicated genotypes are shown as the mean + SEM with the number of separate experiments including 50-250 cells/experiment indicated above the bars. Data acquired from heterozygous animals were similar to wild-type littermates and combined as "controls" (black bar). Proportion of LPA (100-300 nm)-sensitive cells is shown for controls in the presence of $10 \mu \mathrm{M}$ Ki16425 (controls $+\mathrm{Ki}$; blue and white bar), Lpar1 ${ }^{-1-}$ (solid blue bar), Lpar1 ${ }^{-1-}$ in the presence of $10 \mu \mathrm{M}$ Ki16425 (blue striped bar), Lpar2 $^{-/-}$(green bar), Lpar2 ${ }^{-/-}$in the presence of $10 \mu \mathrm{M}$ Ki16425 (orange striped bar), and Lpar1 $^{-1-}$; Lpar2 ${ }^{-1-} ;$ Lpar3 $^{-1-}$ cells (orange bar). Positive controls were included in all experiments. Significant differences were determined using one-way ANOVA with Tukey's post hoc multiple-comparison test. All genotypes were statistically different from controls $\left(^{* *} p<\right.$ 0.001); there was no statistical difference between controls $+\mathrm{Ki}, \mathrm{Lpar}^{-1-}, \mathrm{Lpar}^{-1-}+\mathrm{Ki}$, and $L$ par $2^{-1-}$; however, these cultures revealed statistically significant differences compared with $L$ par $2^{-1-}+\mathrm{Ki}$, and the triple knock-out. The latter were not statistically different (supplemental Table $1 B$, available at www.jneurosci.org as supplemental material).

expressing $\mathrm{LPA}_{1 / 3}$ as well as Ki16425-insensitive receptors (possibly $\mathrm{LPA}_{2}$ and/or $\mathrm{LPA}_{4 / 5}$ or non-receptor-mediated mechanisms). The character of $\mathrm{Ca}_{\mathrm{i}}^{2+}$ responses observed in the presence ("Ki16425-insensitive") and absence of Ki16425 included transient, prolonged, oscillatory, and decreased responses in approximately similar proportions (data not shown). Similar results were obtained with a second, structurally distinct $\mathrm{LPA}_{1 / 3}$ antagonist, VPC 32183( S) (data not shown).

Genetic manipulations revealed that $\mathrm{LPA}_{1}$ is the predominant Ki16425-sensitive receptor mediating LPA-induced $\mathrm{Ca}_{\mathrm{i}}^{2+}$ signaling in NPCs

Since there were detectable levels of $\mathrm{LPA}_{3}$ in cortical tissue used for these studies, and in situ studies indicated a low level of expression throughout the embryonic brain (McGiffert et al., 2002), we used both genetic and pharmacological tools to investigate whether $\mathrm{LPA}_{3}$ modulated $\mathrm{Ca}_{i}^{2+}$. Significantly fewer $\mathrm{Ca}_{i}^{2+}$ responses were observed in cultures derived from mice lacking $\mathrm{LPA}_{1}$ compared with those from littermate controls after 3 min DMSO exposure [Lpar1 ${ }^{-/-}, 44 \pm 4 \%(n=8)$, vs Lpar1 ${ }^{+/-}, 68 \pm$ $3 \%(n=10) ; p<0.01]$. Lpar1 ${ }^{+/-}$embryos were phenotypically similar to wild type, indicating a lack of haploinsufficiency. The $\sim 30 \%$ reduction in LPA sensitivity in cells lacking LPA 1 (Fig. 6; supplemental Table $1 B$, available at www.jneurosci.org as supplemental material) was similar to the percentage of LPA re- 
sponses observed during application of Ki16425 (10 $\mu \mathrm{M})$ [Fig. 6, controls $+\mathrm{Ki}$ (blue bar with white stripes) compared with Lpar1 $^{-1-}$ (solid blue bar)]. In an attempt to address whether $\mathrm{LPA}_{3}$ plays a role in calcium signaling in these cultures, we tested whether LPA responsiveness could be acquired after at least 15 min washout of Ki16425 in Lpar1 ${ }^{-/-}$-derived cultures. Although Ki16425 may slightly reduce the proportion of responsive cells from Lpar1 ${ }^{-1-}$ littermates (Fig. 6, Lpar1 ${ }^{-1-}+\mathrm{Ki}, 33 \pm 7 \%$; $n=$ 6) compared with DMSO-treated controls (Fig. 6, Lpar1 ${ }^{-1-}$ ), the difference was not significant $(p>0.05)$. However, inspecting the phenotypes of individual cells, a rare $L \mathrm{parl}^{-1-}$ population (which included nestin ${ }^{+} / \mathrm{TuJ1} 1^{-}$, nestin ${ }^{+} / \mathrm{Tu} 1^{+}$, and nestin ${ }^{-} /$ $\mathrm{TuJ}^{+}$cells) was observed that exhibited no response to two exposures of LPA ( $300 \mathrm{nM}$ ) during 13 min incubation in Ki16425 $(10 \mu \mathrm{M})$, but LPA sensitivity developed after extensive washout of the antagonist (data not shown), suggesting the presence of $\mathrm{LPA}_{3}$-dependent responses in a small proportion of cells. The responses remaining after $\mathrm{LPA}_{1}$ block or genetic deletion included the full complement of heterogeneous profiles as observed in control cells (data not shown). These results indicate that $\mathrm{LPA}_{1}$ is the predominant Kil6425-sensitive receptor activating $\mathrm{Ca}_{\mathrm{i}}^{2+}$ responses in NPCs.

Genetic manipulations revealed that $\mathrm{LPA}_{2}$ is the predominant Ki16425-insensitive receptor mediating LPA-induced $\mathrm{Ca}_{i}^{2+}$ signaling in NPCs

We next used genetic approaches to determine whether LPAevoked Ki16425-insensitive calcium responses were entirely mediated by $\mathrm{LPA}_{2}$. Approximately $40 \%$ of the nestin ${ }^{+}$cells derived from Lpar2 $^{-1-}$ embryos revealed an LPA response (Fig. 6, Lpar $\left.2^{-I-}\right)$, a reduction of $\sim 30 \%$ compared with littermate controls $\left[\right.$ Lpar2 $\left.^{+/-}, 64 \pm 4 \%(n=11) ; p<0.01\right]$. In the presence of Ki16425 to block $\mathrm{LPA}_{1}$ (and any $\mathrm{LPA}_{3}$ ) receptors, only $\sim 10 \%$ of the Lpar2 $^{-1-}$ cells still responded to $300 \mathrm{~nm}$ LPA (Fig. 6, Lpar $^{-/-}+\mathrm{Ki}$, orange striped bar), consistent with the hypothesis that $\mathrm{LPA}_{1}$ and $\mathrm{LPA}_{2}$ play predominant roles in LPA induced calcium signaling. The remaining sensitivity to LPA is likely mediated by activation of another Kil6425-insensitive receptor (e.g., $\mathrm{LPA}_{4}$ or $\mathrm{LPA}_{5}$ ) since similar proportions of cells were activated by LPA ( $300 \mathrm{nM})$ in NPCs derived from mice lacking all three receptors, $\mathrm{LPA}_{1}, \mathrm{LPA}_{2}$, and $\mathrm{LPA}_{3}\left(\mathrm{Lpar1}^{-1-}\right.$; $\mathrm{Lpar2}^{-/-}$; Lpar $^{-I-}$ ) (Fig. 6, orange bar). These results indicate that $\mathrm{LPA}_{2}$ is the predominant Ki16425-insensitive receptor activating $\mathrm{Ca}^{2+}$ responses in NPCs, but one or more additional receptors are functionally expressed.

\section{S1P activates most LPA-sensitive NPCs}

To address whether the deletion of LPA receptors specifically reduced LPA responsiveness, we tested NPCs derived from wildtype, single (Lpar1 ${ }^{-1-}$ and $L$ par2 ${ }^{-/}$), and triple knock-out animals ( Lpar $^{-I-} ;$ Lpar $^{-1-} ;$ Lpar $\left.^{-1-}\right)$ for their responsiveness to the closely related signaling lipid S1P $(1 \mu \mathrm{M})$ at the end of each experiment. The percentage of S1P-responsive cells was similar in all LPA receptor genetic backgrounds, including $\mathrm{Lparl}^{-1-}$; Lpar2 $2^{-/-} ;$Lpar $^{-/-}$(Fig. 7). This indicates that the genetic and pharmacological manipulations performed in this study are specific to LPA receptor-mediated $\mathrm{Ca}^{2+}$ responses rather than general signaling mechanisms. Calcium responses evoked by S1P revealed heterogeneity in response types as observed for LPA: $\sim 20 \%$ were transient (response decayed to baseline within $100 \mathrm{~s}$ ), $60 \%$ extended beyond 100 s including a secondary increase, $16 \%$ revealed oscillations, and 4\%, an undershoot. Furthermore, this

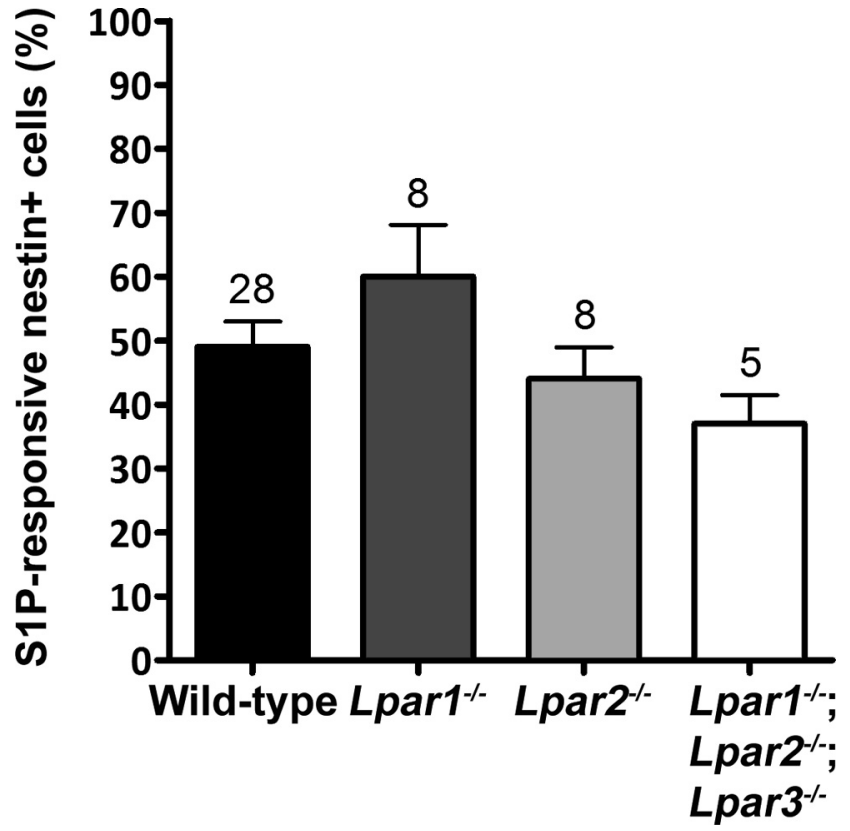

Figure 7. S1P sensitivity is similar in all LPA receptor genotypes tested. The percentage of responsive cells to $1 \mu \mathrm{M}$ S1P is shown for wild-type (black bar), Lpar1 ${ }^{-1-}$ (dark gray bar), Lpar2 $^{-1-}$ (light gray bar), and Lpar1 ${ }^{-1-} ;$ Lpar2 ${ }^{-1-} ;$ Lpar $^{-1-}$ (white bar) NPCS. All comparisons reveal no significant differences ( $p>0.05$, using one-way ANOVA, with Tukey's post hoc multiple-comparison test) (GraphPad Prism 4.0). Error bars indicate SEM.

provides evidence for potential functional redundancy between LPA and S1P signaling systems.

\section{Discussion}

The importance of LPA signaling in brain development has been underscored by receptor expression studies and mouse knockout strategies. Specifically, $\mathrm{LPA}_{1}$-deficient mice exhibit defects in cerebral development (Estivill-Torrús et al., 2008), show altered responses in ex vivo cortical cultures (Kingsbury et al., 2003; Rehen et al., 2006), and show abnormal behaviors consistent with pathologies such as schizophrenia (Harrison et al., 2003) (for review, see Herr and Chun, 2007). During embryonic development, electrophysiological responses had been observed in NPCs (Dubin et al., 1999), yet their activating mechanism(s) were unknown. An expectation extending from LPA receptor gene expression in the cortical VZ was the existence of LPA receptormediated actions on cortical NPCs. This study demonstrates for the first time that diverse calcium responses are regulated by specific LPA receptors in the developing mammalian neocortex. Notably, the extracellular stimulus is in fact a lipid and has a more pervasive effect on NPC calcium signaling than glutamate, PACAP, or ATP at this stage in early corticogenesis. Submicromolar concentrations of LPA were found to modulate intracellular calcium levels in the majority of nestin-immunoreactive putative neuroblasts. The responses are mediated by multiple cognate receptors, but predominantly by $\mathrm{LPA}_{1}$ and $\mathrm{LPA}_{2}$. At the early stage of development chosen for these studies (E12.5), the cortical anlage consists of a proliferative neuroepithelium - the VZ_-bordering the lateral ventricle and composed predominantly of NPCs, compared with a narrow preplate below the pial surface composed of postmitotic neurons (Bayer and Altman, 1991; Dubin et al., 1999; Maric et al., 2000a; Wonders and Anderson, 2005). The cell population most affected by LPA is undifferentiated nestin-immunoreactive NPCs. Interestingly, we 
show that calcium signaling in individual NPCs is often complex and reveals a previously unrecognized heterogeneity and sensitivity: cells express different combinations of functional receptors and exhibit calcium responses with variable cell-specific dynamics. Furthermore, a large proportion of LPA-responsive cells are also sensitive to the bioactive phospholipid S1P. It is likely that the overlap of these systems serves to protect essential cellular processes during brain development.

The characteristics of the observed LPA-induced responses revealed striking heterogeneity and were dependent on both release of calcium from intracellular stores and influx of external calcium. In developing neuronal systems, temporal differences in $\mathrm{Ca}_{\mathrm{i}}^{2+}$ fluctuations have been shown to differentially affect cellular behavior in developmental processes including neuronal differentiation, proliferation, and migration (Gu and Spitzer, 1995; Behar et al., 1996, 1999; Komuro and Rakic, 1998; Flint et al., 1999; Maric et al., 2000a; Owens et al., 2000; Opitz et al., 2002; Ciccolini et al., 2003; Spitzer et al., 2004; Weissman et al., 2004; Calderon et al., 2005; Komuro and Kumada, 2005; Kumada et al., 2006). Receptor-mediated and spontaneous $\mathrm{Ca}_{i}^{2+}$ fluctuations have been demonstrated to play diverse roles in nervous system development including differentiation of neural cell phenotype (Gu and Spitzer, 1995; Spitzer et al., 2000, 2004), chemotaxis (Kumada and Komuro, 2004; Komuro and Kumada, 2005), and proliferation (Lory et al., 2006). With regard to the developing mammalian cortex, $\mathrm{Ca}_{\mathrm{i}}^{2+}$ signaling pathways have been demonstrated to regulate progenitor and differentiated cell production (LoTurco et al., 1995; Haydar et al., 2000; Weissman et al., 2004), and dysregulated $\mathrm{Ca}_{\mathrm{i}}^{2+}$ signaling may underlie certain neurological diseases with developmental etiologies (Caviness et al., 1995). Thus, controlled regulation of calcium signaling is important for proper cortical development (Konur and Ghosh, 2005). To achieve differential $\mathrm{Ca}_{\mathrm{i}}^{2+}$ signaling, cells encode the signal in distinct spatiotemporal patterns using mechanisms that release $\mathrm{Ca}^{2+}$ from intracellular stores and/or that modulate the flux of $\mathrm{Ca}^{2+}$ across the plasma membrane (Berridge et al., 2000; Meyer zu Heringdorf, 2004). Thapsigargin-sensitive store release mediates the initial fast transient increase but does not appear to be required for activation of at least a proportion of calcium influx pathways. Although $\mathrm{Ca}_{\mathrm{v}}$ channels play a role in $\mathrm{Ca}^{2+}$ signaling at E16 (Corlew et al., 2004), $\mathrm{Cd}^{2+}$ - and $\mathrm{Ni}^{2+}$-sensitive channels do not appear to contribute significantly to the LPA-induced responses in E12.5 acute cultures. This result is consistent with a previous study on early neurogenesis in rat reporting a paucity of dihydropyridine-sensitive L-type $\mathrm{Ca}_{\mathrm{v}}$ in progenitor cells (Maric et al., 2000b). The insensitivity to $\mathrm{Ca}_{\mathrm{v}}$ channel antagonists and sensitivity to $\mathrm{Gd}^{3+}$ in approximately one-half of the cells suggest that TRPC (TRPC1-3, TRPC6-7) channels may mediate a large proportion of the LPA-induced $\mathrm{Ca}^{2+}$ influx responses (Ramsey et al., 2006; Tai et al., 2009). Receptor-mediated LPA signaling thus broadens the repertoire of extracellular signals modulating intracellular calcium.

Some of the conclusions drawn from this study rely on the interpretation that Ki16425 selectively and completely antagonizes $\mathrm{LPA}_{1}$ and $\mathrm{LPA}_{3}$ in this system. In addition to reported data (Ohta et al., 2003), three lines of evidence indicate Ki16425 is effective under these conditions. First, only $10 \%$ of the cells derived from Lpar2 $^{-1-}$ animals in the presence of Ki16425 were responsive to LPA (Fig. 6) similar to the percentage responsive to LPA in the triple knock-out, Lpar $1^{-/-} /$Lpar $^{-/-} /$Lpar $^{-/-}$. Second, cells that were initially unresponsive to LPA in the presence of Ki16425, revealed LPA-induced $\mathrm{Ca}_{\mathrm{i}}^{2+}$ responses after extensive washout of Ki16425 (Fig. 5). Third, there was no difference in the percentage of responsive wild-type cells in the presence of a higher concentration of Kil6425 (30 $\mu \mathrm{M})$ (data not shown). Thus, we have defined "Ki16425-sensitive" responses as those that are observed on washout of Ki16425 for $>5$ min and are $>150 \%$ the initial response(s) to LPA in the presence of Ki16425. The validity of this criterion is based on the findings that only $2 \%$ of cells revealed a second response to $300 \mathrm{nM}$ LPA that was $>150 \%$ the initial response magnitude (data not shown), and there was no apparent time-dependent increase in LPA responsiveness after initiation of the assay (i.e., the response magnitude was similar whether LPA was applied within $1 \mathrm{~min}$ or $>5 \mathrm{~min}$ after initiating the assay) (data not shown). Approximately onehalf of the wild-type cells produced a response in the presence of the $\mathrm{LPA}_{1 / 3}$ blocker. Importantly, in cells revealing tachyphylaxis of the first Ki16425-insensitive response, a response could be observed after extensive ( $>10 \mathrm{~min}$ ) washout of Kil6425. These data demonstrate that a significant proportion of cells express both Ki16425-sensitive and -insensitive LPA receptors. This result provides the first direct evidence that different LPA receptor subtypes can produce similar downstream effects in the same cells.

Both pharmacological and genetic approaches indicated that $\mathrm{LPA}_{1}$ and $\mathrm{LPA}_{2}$ mediated the majority of responses and at least $30 \%$ of cells revealed responses that were mediated by multiple receptor subtypes. The expression of $\mathrm{LPA}_{1}$ is highly enriched in the VZ with low expression in the postmitotic cortical plate. This expression declines dramatically over the course of embryonic corticogenesis such that in situ analyses identified very few labeled cells by E18 (Hecht et al., 1996). Furthermore, LPAinduced $\left[{ }^{35} \mathrm{~S}\right] \mathrm{GTP} \gamma \mathrm{S}$ labeling of tissue sections from embryonic brain decreases between E12 and E18 indicated that, overall, there appears to be a decrease in LPA receptor activation of G-proteins during this period (Harada et al., 2004). This decrease in LPA receptor expression and activity with differentiation is consistent with the responsivity of cortical cells reported in this study whereby NPCs were more responsive than differentiated young neurons. Thus, a much higher percentage of nestin ${ }^{+}$ NPCs from the VZ $(\sim 75 \%)$ responded to LPA relative to postmitotic, $\mathrm{TuJ} 1+$ neurons $(\sim 25 \%)$ that primarily reside in the cortical plate. This is likely to reflect a spatial, basal-to-apical signaling gradient during cortical development that may regulate such processes as migration of differentiating neuroblasts. Importantly, compared with known activators of NPC calcium signaling, the lysophospholipids LPA and S1P represent the broadest extracellular activators yet identified.

The known LPA receptors signal through heterotrimeric G-proteins, many of which are shared by single receptor subtypes (Ishii et al., 2004; Gardell et al., 2006). Important exceptions include the lack of $\mathrm{LPA}_{3}$ coupling to $\mathrm{G}_{\alpha 12 / 13}$ and the coupling of $\mathrm{LPA}_{4}$ to $\mathrm{G}_{\alpha \mathrm{s}}$. Although intracellular signaling pathways show considerable cross talk, the interactions of $G_{\alpha 12 / 13}$ and $G_{\alpha s}$ with the $\mathrm{Ca}^{2+}$ signaling pathway in developing cortex is poorly defined. It is possible that, in the present studies, $\mathrm{LPA}_{2}$ [but not $\mathrm{LPA}_{1}$ (or $\mathrm{LPA}_{3}$ if present)] will influence $\mathrm{Ca}_{\mathrm{i}}^{2+}$ homeostasis via an interaction with NHERF2 $\left(\mathrm{Na}^{+} / \mathrm{H}^{+}\right.$exchanger regulatory factor 2 ) to potentiate PLC $\beta$ (phospholipase $C \beta$ ) activation (Oh et al., 2004). We found no evidence for a significant role of $G_{\alpha i} / G_{\alpha o}$ activation of calcium signaling by LPA. The expression of multiple LPA receptor subtypes within the same cell and the responsivity of many neuroblasts to both LPA and S1P indicate that there are multiple levels of modulation that regulate lysophospholipid-mediated calcium signaling, with additional complexity produced by preferences for distinct chemical forms of LPA by 
some receptor subtypes (Bandoh et al., 2000). The potential for LPA to influence cortical development through specific $\mathrm{Ca}_{i}^{2+}$ signaling pathways that may ultimately modulate transcription, cell cycle, cell death, chemotaxis, and neuronal differentiation could lead to a better understanding of basic cellular mechanisms underlying neurodevelopment, as well as those contributing to neuropsychiatric disorders with developmental etiologies.

\section{References}

Aizawa H, Hu SC, Bobb K, Balakrishnan K, Ince G, Gurevich I, Cowan M, Ghosh A (2004) Dendrite development regulated by CREST, a calciumregulated transcriptional activator. Science 303:197-202.

Albrieux M, Platel JC, Dupuis A, Villaz M, Moody WJ (2004) Early expression of sodium channel transcripts and sodium current by Cajal-Retzius cells in the preplate of the embryonic mouse neocortex. J Neurosci 24:1719-1725.

An S, Bleu T, Zheng Y, Goetzl EJ (1998) Recombinant human G proteincoupled lysophosphatidic acid receptors mediate intracellular calcium mobilization. Mol Pharmacol 54:881-888.

Bandoh K, Aoki J, Hosono H, Kobayashi S, Kobayashi T, MurakamiMurofushi K, Tsujimoto M, Arai H, Inoue K (1999) Molecular cloning and characterization of a novel human G-protein-coupled receptor, EDG7, for lysophosphatidic acid. J Biol Chem 274:27776-27785.

Bandoh K, Aoki J, Taira A, Tsujimoto M, Arai H, Inoue K (2000) Lysophosphatidic acid (LPA) receptors of the EDG family are differentially activated by LPA species. Structure-activity relationship of cloned LPA receptors. FEBS Lett 478:159-165.

Bayer SA, Altman J (1991) Neocortical development. New York: Raven.

Behar TN, Li YX, Tran HT, Ma W, Dunlap V, Scott C, Barker JL (1996) GABA stimulates chemotaxis and chemokinesis of embryonic cortical neurons via calcium-dependent mechanisms. J Neurosci 16:1808-1818.

Behar TN, Scott CA, Greene CL, Wen X, Smith SV, Maric D, Liu QY, Colton CA, Barker JL (1999) Glutamate acting at NMDA receptors stimulates embryonic cortical neuronal migration. J Neurosci 19:4449-4461.

Berridge MJ, Lipp P, Bootman MD (2000) The versatility and universality of calcium signalling. Nat Rev Mol Cell Biol 1:11-21.

Biagi BA, Enyeart JJ (1990) Gadolinium blocks low- and high-threshold calcium currents in pituitary cells. Am J Physiol 259:C515-C520.

Calderon DP, Leverkova N, Peinado A (2005) Gq/11-induced and spontaneous waves of coordinated network activation in developing frontal cortex. J Neurosci 25:1737-1749.

Caviness VS Jr, Takahashi T, Nowakowski RS (1995) Numbers, time and neocortical neuronogenesis: a general developmental and evolutionary model. Trends Neurosci 18:379-383.

Choi JW, Herr DR, Noguchi K, Yung YC, Lee CW, Mutoh T, Lin ME, Teo ST, Park KE, Mosley AN, Chun J (2010) LPA receptors: subtypes and biological actions. Annu Rev Pharmacol Toxicol 50:157-186.

Ciccolini F, Collins TJ, Sudhoelter J, Lipp P, Berridge MJ, Bootman MD (2003) Local and global spontaneous calcium events regulate neurite outgrowth and onset of GABAergic phenotype during neural precursor differentiation. J Neurosci 23:103-111.

Contos JJ, Chun J (2001) The mouse lp(A3)/Edg7 lysophosphatidic acid receptor gene: genomic structure, chromosomal localization, and expression pattern. Gene 267:243-253.

Contos JJ, Fukushima N, Weiner JA, Kaushal D, Chun J (2000) Requirement for the lpA1 lysophosphatidic acid receptor gene in normal suckling behavior. Proc Natl Acad Sci U S A 97:13384-13389.

Contos JJ, Ishii I, Fukushima N, Kingsbury MA, Ye X, Kawamura S, Brown JH, Chun J (2002) Characterization of lpa2 (Edg4) and lpa1/lpa2 (Edg2/ Edg4) lysophosphatidic acid receptor knockout mice: signaling deficits without obvious phenotypic abnormality attributable to lpa2. Mol Cell Biol 22:6921-6929.

Corbin JG, Gaiano N, Juliano SL, Poluch S, Stancik E, Haydar TF (2008) Regulation of neural progenitor cell development in the nervous system. J Neurochem 106:2272-2287.

Corlew R, Bosma MM, Moody WJ (2004) Spontaneous, synchronous electrical activity in neonatal mouse cortical neurones. J Physiol 560:377-390.

Das AK, Hajra AK (1989) Quantification, characterization and fatty acid composition of lysophosphatidic acid in different rat tissues. Lipids 4:329-333.

Dubin AE, Bahnson T, Weiner JA, Fukushima N, Chun J (1999) Lysophos- phatidic acid stimulates neurotransmitter-like conductance changes that precede GABA and L-glutamate in early, presumptive cortical neuroblasts. J Neurosci 19:1371-1381.

Estivill-Torrús G, Llebrez-Zayas P, Matas-Rico E, Santín L, Pedraza C, De Diego I, Del Arco I, Fernández-Llebrez P, Chun J, De Fonseca FR (2008) Absence of LPA1 signaling results in defective cortical development. Cereb Cortex 18:938-950.

Flint AC, Dammerman RS, Kriegstein AR (1999) Endogenous activation of metabotropic glutamate receptors in neocortical development causes neuronal calcium oscillations. Proc Natl Acad Sci U S A 96:12144-12149.

Fukushima N, Weiner JA, Chun J (2000) Lysophosphatidic acid (LPA) is a novel extracellular regulator of cortical neuroblast morphology. Dev Biol 228:6-18.

Fukushima N, Weiner JA, Kaushal D, Contos JJ, Rehen SK, Kingsbury MA, Kim KY, Chun J (2002) Lysophosphatidic acid influences the morphology and motility of young, postmitotic cortical neurons. Mol Cell Neurosci 20:271-282.

Fukushima N, Shano S, Moriyama R, Chun J (2007) Lysophosphatidic acid stimulates neuronal differentiation of cortical neuroblasts through the LPA1-Gi/o pathway. Neurochem Int 50:302-307.

Gardell SE, Dubin AE, Chun J (2006) Emerging medicinal roles for lysophospholipid signaling. Trends Mol Med 12:65-75.

Gu X, Spitzer NC (1995) Distinct aspects of neuronal differentiation encoded by frequency of spontaneous $\mathrm{Ca}^{2+}$ transients. Nature 375:784787.

Harada J, Foley M, Moskowitz MA, Waeber C (2004) Sphingosine-1phosphate induces proliferation and morphological changes of neural progenitor cells. J Neurochem 88:1026-1039.

Harrison SM, Reavill C, Brown G, Brown JT, Cluderay JE, Crook B, Davies CH, Dawson LA, Grau E, Heidbreder C, Hemmati P, Hervieu G, Howarth A, Hughes ZA, Hunter AJ, Latcham J, Pickering S, Pugh P, Rogers DC, Shilliam CS, et al. (2003) LPA1 receptor-deficient mice have phenotypic changes observed in psychiatric disease. Mol Cell Neurosci 24:11701179 .

Haydar TF, Wang F, Schwartz ML, Rakic P (2000) Differential modulation of proliferation in the neocortical ventricular and subventricular zones. J Neurosci 20:5764-5774.

Hecht JH, Weiner JA, Post SR, Chun J (1996) Ventricular zone gene-1 (vzg-1) encodes a lysophosphatidic acid receptor expressed in neurogenic regions of the developing cerebral cortex. J Cell Biol 135:1071-1083.

Herr D, Chun J (2007) Effects of LPA and S1P on the nervous system and implications for their involvement in disease. Curr Drug Targets 8:155-167.

Hille B (2001) Ion channels of excitable membranes, Ed 3. Sunderland, MA: Sinauer Associates.

Ishii I, Fukushima N, Ye X, Chun J (2004) Lysophospholipid receptors: signaling and biology. Annu Rev Biochem 73:321-354.

Kingsbury MA, Rehen SK, Contos JJ, Higgins CM, Chun J (2003) Nonproliferative effects of lysophosphatidic acid enhance cortical growth and folding. Nat Neurosci 6:1292-1299.

Komuro H, Kumada T (2005) $\mathrm{Ca}^{2+}$ transients control CNS neuronal migration. Cell Calcium 37:387-393.

Komuro H, Rakic P (1998) Orchestration of neuronal migration by activity of ion channels, neurotransmitter receptors, and intracellular Ca fluctuations. J Neurobiol 37:110-130.

Konur S, Ghosh A (2005) Calcium signaling and the control of dendritic development. Neuron 46:401-405.

Kumada T, Komuro H (2004) Completion of neuronal migration regulated by loss of $\mathrm{Ca}^{2+}$ transients. Proc Natl Acad Sci U S A 101:8479-8484.

Kumada T, Lakshmana MK, Komuro H (2006) Reversal of neuronal migration in a mouse model of fetal alcohol syndrome by controlling secondmessenger signalings. J Neurosci 26:742-756.

Lee CW, Rivera R, Gardell S, Dubin AE, Chun J (2006) GPR92 as a new G12/13- and Gq-coupled lysophosphatidic acid receptor that increases cAMP, LPA5. J Biol Chem 281:23589-23597.

Lee CW, Rivera R, Dubin AE, Chun J (2007) LPA4/GPR23 is an LPA receptor utilizing Gs, Gq/Gi-mediated calcium signaling and G12/13-mediated Rho activation. J Biol Chem 282:4310-4317.

Lory P, Bidaud I, Chemin J (2006) T-type calcium channels in differentiation and proliferation. Cell Calcium 40:135-146.

LoTurco JJ, Kriegstein AR (1991) Clusters of coupled neuroblasts in embryonic neocortex. Science 252:563-566. 
LoTurco JJ, Owens DF, Heath MJ, Davis MB, Kriegstein AR (1995) GABA and glutamate depolarize cortical progenitor cells and inhibit DNA synthesis. Neuron 15:1287-1298.

Maric D, Maric I, Barker JL (2000a) Developmental changes in cell calcium homeostasis during neurogenesis of the embryonic rat cerebral cortex. Cereb Cortex 10:561-573.

Maric D, Maric I, Chang YH, Barker JL (2000b) Stereotypical physiological properties emerge during early neuronal and glial lineage development in the embryonic rat neocortex. Cereb Cortex 10:729-747.

McGiffert C, Contos JJ, Friedman B, Chun J (2002) Embryonic brain expression analysis of lysophospholipid receptor genes suggests roles for s1p1 in neurogenesis and s1p1-3 in angiogenesis. FEBS Lett 531:103-108.

Meyer zu Heringdorf D (2004) Lysophospholipid receptor-dependent and -independent calcium signaling. J Cell Biochem 92:937-948.

Nicot A, DiCicco-Bloom E (2001) Regulation of neuroblast mitosis is determined by PACAP receptor isoform expression. Proc Natl Acad Sci U S A 98:4758-4763.

Noguchi K, Ishii S, Shimizu T (2003) Identification of p2y9/GPR23 as a novel $\mathrm{G}$ protein-coupled receptor for lysophosphatidic acid, structurally distant from the Edg family. J Biol Chem 278:25600-25606.

Oh YS, Jo NW, Choi JW, Kim HS, Seo SW, Kang KO, Hwang JI, Heo K, Kim SH, Kim YH, Kim IH, Kim JH, Banno Y, Ryu SH, Suh PG (2004) NHERF2 specifically interacts with LPA2 receptor and defines the specificity and efficiency of receptor-mediated phospholipase C- $\beta 3$ activation. Mol Cell Biol 24:5069-5079.

Ohta H, Sato K, Murata N, Damirin A, Malchinkhuu E, Kon J, Kimura T, Tobo M, Yamazaki Y, Watanabe T, Yagi M, Sato M, Suzuki R, Murooka H, Sakai T, Nishitoba T, Im DS, Nochi H, Tamoto K, Tomura H, et al. (2003) Ki16425, a subtype-selective antagonist for EDG-family lysophosphatidic acid receptors. Mol Pharmacol 64:994-1005.

Ohuchi H, Hamada A, Matsuda H, Takagi A, Tanaka M, Aoki J, Arai H, Noji S (2008) Expression patterns of the lysophospholipid receptor genes during mouse early development. Dev Dyn 237:3280-3294.

Okada H, Miyakawa N, Mori H, Mishina M, Miyamoto Y, Hisatsune T (2003) NMDA receptors in cortical development are essential for the generation of coordinated increases in $\left[\mathrm{Ca}^{2+}\right]_{\mathrm{i}}$ in "neuronal domains." Cereb Cortex 13:749-757.
Opitz T, De Lima AD, Voigt T (2002) Spontaneous development of synchronous oscillatory activity during maturation of cortical networks in vitro. J Neurophysiol 88:2196-2206.

Owens DF, Kriegstein AR (1998) Patterns of intracellular calcium fluctuation in precursor cells of the neocortical ventricular zone. J Neurosci 18:5374-5388.

Owens DF, Flint AC, Dammerman RS, Kriegstein AR (2000) Calcium dynamics of neocortical ventricular zone cells. Dev Neurosci 22:25-33.

Ramsey IS, Delling M, Clapham DE (2006) An introduction to TRP channels. Annu Rev Physiol 68:619-647.

Rehen SK, Kingsbury MA, Almeida BS, Herr DR, Peterson S, Chun J (2006) A new method of embryonic culture for assessing global changes in brain organization. J Neurosci Methods 158:100-108.

Spitzer NC, Lautermilch NJ, Smith RD, Gomez TM (2000) Coding of neuronal differentiation by calcium transients. Bioessays 22:811-817.

Spitzer NC, Root CM, Borodinsky LN (2004) Orchestrating neuronal differentiation: patterns of $\mathrm{Ca}^{2+}$ spikes specify transmitter choice. Trends Neurosci 27:415-421.

Suh J, Lu N, Nicot A, Tatsuno I, DiCicco-Bloom E (2001) PACAP is an anti-mitogenic signal in developing cerebral cortex. Nat Neurosci 4:123-124.

Tai Y, Feng S, Du W, Wang Y (2009) Functional roles of TRPC channels in the developing brain. Pflugers Arch 458:283-289.

Weissman TA, Riquelme PA, Ivic L, Flint AC, Kriegstein AR (2004) Calcium waves propagate through radial glial cells and modulate proliferation in the developing neocortex. Neuron 43:647-661.

Wonders C, Anderson SA (2005) Cortical interneurons and their origins. Neuroscientist 11:199-205.

Yanagida K, Ishii S, Hamano F, Noguchi K, Shimizu T (2007) LPA4/p2y9/ GPR23 mediates Rho-dependent morphological changes in a rat neuronal cell line. J Biol Chem 282:5814-5824.

Ye X (2008) Lysophospholipid signaling in the function and pathology of the reproductive system. Hum Reprod Update 14:519-536.

Ye X, Hama K, Contos JJ, Anliker B, Inoue A, Skinner MK, Suzuki H, Amano T, Kennedy G, Arai H, Aoki J, Chun J (2005) LPA3-mediated lysophosphatidic acid signalling in embryo implantation and spacing. Nature 435: $104-108$. 